J. Egypt. Acad. Soc. Environ. Develop., 18 (1): 1-9 (2017)

E.mail: easedjournal_egypt@yahoo.com

www.eased.byethost13.com
(D-Environmental Studies)

ISSN 1110-8770

eISSN 2314-5471 (online)

\title{
Effect of sea cucumbers Holothuria atra extract on liver and kidney functions in rats
}

\author{
Mohamed A. Hamed ${ }^{1}$, Emad H. Abou El-Naga ${ }^{1}$, Nagat M. Youssef ${ }^{1 *}$ and \\ Sahar S. El-Sakka ${ }^{2}$ \\ 1- National Institute of Oceanography \& Fishery Marine-Suez-Egypt \\ 2- Chemistry Department, Faculty of Science, Suez University-Egypt \\ *Corresponding Author: E-mail: drnmy@yahoo.com
}

\begin{abstract}
Sea cucumbers are an abundant group of motile reef invertebrates. They have a special organ called Cuvierian organ that contains toxic substances. The present study aims to show the effect of the sublethal dose of the extract of sea cucumber Holathuria arta on liver and kidney functions in rats at different intervals (half hour, one hour, 6 hours, 12 hours and 24 hours). Specimens of sea cucumbers were collected from the Red sea, Egypt.

The sublethal dose $\left(\mathrm{LD}_{25}\right)$ of the extract of sea cucumber Holothuria atra showed that GOT/AST was not significantly affected although serum GPT/ALT (normal serum level $70.8 \pm 3.25 \mathrm{~g} / \mathrm{L}$ ) was significantly increased reaching maximum value after 6 hours of injection $(90.3 \%)$ then decreased throughout the experiment. Serum albumin wasn't significantly affected after injection with $\left(\mathrm{LD}_{25}\right)$. Also, the total protein didn't show significant change.

The kidney function of the rat was measured by urea and creatinine after injection of $\left(\mathrm{LD}_{25}\right)$ of the extract of sea cucumber Holothuria atra. Urea level showed a sharp significant increase and reaching its maximum value after 6 hours of injection (122\%), then decreased throughout the experimental period and became non significantly effective after 12 hours. On the other hand, creatinine also showed a significant increase reaching maximum value after 6 hours of injection (112.5\%) then decreased through the experiment as urea but it reached normal level after 24 hours.

In conclusion, the extract toxin of sea cucumber of Holothuria atra has direct effect on ALT with no other effect on liver function test parameters, while it has sharp effect on kidney function test parameters.
\end{abstract}

Key words: Sea Cucumbers, liver Function; Kidney Function; Holothuria atra.

\section{INTRODUCTION}

Sea cucumbers are marine invertebrates that belonging to the class Holothuroidea and there are more than 1,400 species, of which only over 20 species are edible (Kerr and Kim, 2001). Sea cucumbers are a traditional sea food and important medical material in Asian countries to treat wound, eczema, arthritis, hypertension and impotence (Ridzwan, 2007). They have valuable nutrients such as Vitamin A, Vitamin B1 (thiamine), Vitamin B2 (riboflavin), Vitamin B3 (niacin), and minerals, especially calcium, magnesium, iron and zinc. A number of unique biological and pharmacological activities including anti-angiogenic, anticancer, anticoagulant, anti-hypertension, anti-inflammatory, antimicrobial, antioxidant, antithrombotic, antitumor and wound healing have been ascribed to various species of sea cucumbers.

Several studies have shown multiple biological activities of sea cucumber species, including the potential activity of their coelomic fluid (Hawa et al., 1999), their antinociceptive 
Mohamed A. Hamed et al.

(Ridzawan et al., 2001), antibacterial, antifungal and antiproliferative activities and promotion of wound healing of the tissue extract (Althunibate et al., 2009).

Although sea cucumbers have been the subject of various investigations by many authors, yet those of the Red sea species have received little attention and most of the studies are mainly taxonomic (Clark, 1967 ; Hasan, 2001) and few studies were done on the ecology and biology of these animals (Hasan, 2003 ; Hasan, 2004). In spite of the increasing interest in pharmacology of holothurians all over the world nowadays, there is rare work done on the Liver and kidney function effect of the Red Sea holothurians. Therefore this study aims to investigate the effect of sea cucumbers Holothuria atra extract from the Red sea on liver and kidney functions of rats

\section{Animals:}

\section{MATERIALS AND METHODS}

Adult female Swiss albino rats weighing 130-250 g were purchased from the breeding unit of the Egyptian Stock Holding Company for Biological products of Vaccines and Sera (VACSERA). They were housed in steel mesh cages (5 rats/ cage) in the animal house of National Institute of Oceanography and Fisheries (NIOF), Suez and Aqaba Gulfs branch) and maintained on a commercial pellet diet and tap water for one week before starting the experiment as an acclimatization period.

140 Young and adult male Swiss albino rats were used for determination of the lethal $\left(\mathrm{LD}_{100}\right)$, the acute median $\left(\mathrm{LD}_{50}\right)$ and the sublethal $\left(\mathrm{LD}_{25}\right)$ doses of the sea cucumber extract according to Reed and Meuench (1938).

Specimens of sea cucumbers (Holothuria atria) of 150-200 g each, were hand collected from Hurghada on the Red Sea.

\section{Preparation of Sea cucumber Extracts (Hot water Extraction)}

The extraction technique was adopted from Fredalina et al. (1999). The animals were cut into small parts by a sharp knife, finely ground in a blender then poured in petri dishes. The petri dishes were weighed then put in an oven at $70^{\circ} \mathrm{C}(18-20 \mathrm{~h})$ until no change in weight was observed. The dried samples were further blended until a fine powder was produced. Precisely $12 \mathrm{~g}$ of the powder were mixed with dist. Water in $100 \mathrm{~mL}$ flask. The mixture was shook, then centrifuged at $3000 \mathrm{rpm}$ for 20 minutes and the supernatant was separated and preserved at $4{ }^{\circ} \mathrm{C}$. The residue was further extracted (x2) using 40 and $20 \mathrm{~mL}$ of PBS, respectively. The supernatants were combined in a round-bottom flask, and then freeze-dried at $-50^{\circ} \mathrm{C}$ to produce a powder-like extract (Biochemistry Laboratory, National Institute of Oceanography and Fisheries (NIOF), Suez and Aqaba Gulfs branch).

\section{Determination of Serum Alanine Aminotransferase (ALT) and Asprtate Aminotransferase (AST) activities}

The ALT activity was measured by the conversion of alanine and oxoglutarate to pyruvate and glutamate. The AST activity was measured by the conversion of Aspartet and oxoglutarate to oxalacetate and glutamate. The catalytic concentration was determined from the rate of decreasing of NADH at $340 \mathrm{~nm}$, by means of lactate dehydrogenase (LDH) coupled reaction. The level of serum ALT and AST activities was determined by Automated Systems by (Bio systems analyzer A25) method of Gella et al. (1985) using commercial available specific kits (Spain; Biosystems S.A). 


\section{Effect of sea cucumbers Holothuria atra extract on liver and kidney functions in rats}

\section{Determination of Serum Albumin concentration}

Albumin in the sample was reacted with bromocersol green in acid medium forming a colored complex that can be measured by spectrophotometer. The level of serum Albumin concentration were determinate by Automated Biosystems analyzer A25 method of Doumas et al. (1971) using commercial available specific kits (Biosystems S.A. Costa Brava, 30. 08030 Barcelona Spain).

\section{Determination of Serum Protein (total) concentration}

Protein in the sample was reacted with copper (II) ion in alkaline medium forming a colored complex that can be measured by spectrophotometer. The level of serum Protein (total) concentration was determinate by Automated Biosystems analyzer A25 method of Gornall et al. (1949) using commercial available specific kits (Spain; Biosystems S.A).

\section{Determination of Serum Urea concentration}

Urea in the sample consumed, by means of the coupled reactions, NADH that can be measured by spectrophotometer. The levels of serum Urea concentration were determined by Automated Biosystems analyzer A25 method of Gutmann and Bergmeyer (1974), using commercial available specific kits (Spain; Biosystems S.A.).

\section{Determination of Serum Creatinie concentration}

Creatinine reacted with picrate in alkaline medium forming a colored complex. The complex formation rate is measured in a short period to avoid interferences. The levels of serum Creatinine concentration were determinate by Automated Biosystems analyzer A25 method of Fabiny and Ertingshausen (1971), using commercial available specific kits (Spain; Biosystems S.A.).

\section{Statistical Data Analysis:}

Average values were calculated from the individual values of the results obtained, according to the appropriate formula, whereas the standard error was calculated using different formula. The significance was determined by Student $t$-test, in a manner that when making comparison between groups with same number of animals we used the appropriate formula, while making comparison between groups with different number of animals we used the specific formula. The values were compared in special table, and for all analyses, $\mathrm{P}<0.05$ was accepted as a significant probability level. 
Mohamed A. Hamed et al.

Toxicity studies:

\section{RESULTS}

The estimated $\mathrm{LD}_{50}$ for the extract from the sea cucumber Holothuria atra was 3.12 $\mathrm{mg} / \mathrm{Kg}$ rat , while $\mathrm{LD}_{25}$ was $1.55 \mathrm{mg} / \mathrm{Kg}$ rat.

Table (1): Determination of $\mathrm{LD}_{50}$ of the crude toxin of the sea cucumber Holothuria atra.

\begin{tabular}{|c|c|c|c|c|c|c|}
\hline \multirow{2}{*}{$\begin{array}{c}\text { Dose } \\
\text { mg / Kg }\end{array}$} & \multirow{2}{*}{$\begin{array}{l}\text { No. of } \\
\text { Animals }\end{array}$} & \multirow{2}{*}{$\begin{array}{c}\text { Survivals } \\
\text { (S) }\end{array}$} & \multirow{2}{*}{$\begin{array}{r}\text { Death } \\
\text { (D) }\end{array}$} & \multicolumn{2}{|c|}{ Total } & \multirow[t]{2}{*}{$\begin{array}{c}\text { Mortality } \\
\%\end{array}$} \\
\hline & & & & (S) & (D) & \\
\hline 2.0 & 10 & 9 & 1 & 30 & 1 & $3.30 \%$ \\
\hline 2.3 & 10 & 8 & 2 & 20 & 3 & $13.0 \%$ \\
\hline 2.9 & 10 & 7 & 3 & 12 & 6 & $33.3 \%$ \\
\hline 3.4 & 10 & 4 & 6 & 5 & 12 & $70.6 \%$ \\
\hline 4.1 & 10 & 1 & 9 & 1 & 21 & $95.0 \%$ \\
\hline 4.9 & 10 & 0 & 10 & 0 & 31 & $100 \%$ \\
\hline
\end{tabular}

\section{Liver function testes}

The mean level $( \pm$ S.E) of serum GOT/AST in normal rats was found to be $244.7 \pm 9.25 \mathrm{~g} / \mathrm{L}$. Table (2) showed that the level of GOT/AST was not significantly affected in rats injected (i.P) with $\mathrm{LD}_{25}$ of the extract of sea cucumber Holothuria atra throughout the experiment period. However, the level of GOT/ALT was significantly affected in rats injected (i.P) with $\mathrm{LD}_{25}$ of the extract of $H$. atra and a sharp significant increase of GOT/ ALT level was found after 6 hours of injection $(90.3 \% \mathrm{P}<0.05)$, which decreased throughout the experimental period (Table 3).

On the other hand, the levels of albumin (Table 4) and total protein (Table 5) were not significantly affected in rats injected (i.P) with the investigated $\mathrm{LD}_{25}$ throughout the experiment period

Table (2): Effect of sublethal dose $\left(\mathrm{LD}_{25}\right)$ of the hot water extract of sea cucumbers Holothuria atra on GOT /AST of rats compared to normal controls.

\begin{tabular}{|l|c|c|c|c|c|c|c|}
\hline Groups & Number & Mean & S.E & Minimum & Maximum & \% Change & P< \\
\hline Control & 10 & 244.7 & 9.25 & 221 & 316 & - & - \\
\hline 1/2 hrs & 10 & 245.7 & 23.5 & 119 & 379 & 0.4 & N.S \\
\hline $\mathbf{1}$ hrs & 10 & 248.7 & 15.8 & 134 & 314 & 1.6 & N.S \\
\hline 6 hrs & 10 & 246.3 & 9.68 & 212 & 288 & 1.8 & N.S \\
\hline 12 hrs & 10 & 249 & 8.26 & 200 & 293 & 1.9 & N.S \\
\hline
\end{tabular}

The mean level \pm S.E of serum GOT/ ALT in normal rats was found to be $70.8 \pm 3.25 \mathrm{~g} / \mathrm{L}$ 
Effect of sea cucumbers Holothuria atra extract on liver and kidney functions in rats

Table (3): Effect of sublethal dose $\left(\mathrm{LD}_{25}\right)$ of the hot water extract of sea cucumbers Holothuria atra on GPT/ALT of rats compared to normal controls.

\begin{tabular}{|l|c|c|c|c|c|c|c|}
\hline \multicolumn{1}{|c|}{ Groups } & Number & Mean & S.E & Minimum & Maximum & \% Change & P< \\
\hline Control & 10 & 70.8 & 3.25 & 57 & 87 & - & - \\
\hline 1/2 hrs & 10 & 79.6 & 4.77 & 60 & 102 & 12.7 & 0.05 \\
\hline $\mathbf{1}$ hrs & 10 & 88.4 & 7.24 & 59 & 144 & 24.8 & 0.05 \\
\hline 6 hrs & 10 & 134 & 10.4 & 100 & 190 & 90.3 & 0.05 \\
\hline $\mathbf{1 2} \mathbf{h r s}$ & 10 & 116 & 7.09 & 90 & 144 & 63.8 & 0.05 \\
\hline
\end{tabular}

The mean level \pm S.E of serum albumin in normal rats was found to be $3.13 \pm 0.09 \mathrm{~g} / \mathrm{L}$.

Table (4): Effect of sublethal dose $\left(\mathrm{LD}_{25}\right)$ of the hot water extract of sea cucumbers Holothuria atra on Albumin of rats.

\begin{tabular}{|l|l|l|l|l|l|l|l|}
\hline Groups & Number & Mean & S.E & Minimum & Maximum & \%change & P< \\
\hline Control & 10 & 3.13 & 0.09 & 2.7 & 3.7 & - & - \\
\hline 1/2 hrs & 10 & 3.05 & 0.10 & 2.6 & 3.7 & 2.5 & N.S \\
\hline $\mathbf{1}$ hrs & 10 & 2.80 & 0.10 & 2.2 & 3.2 & 10.5 & N.S \\
\hline 6 hrs & 10 & 2.93 & 0.19 & 1.9 & 4.0 & 6.4 & N.S \\
\hline $\mathbf{1 2}$ hrs & 10 & 3.05 & 0.10 & 2.6 & 3.5 & 2.6 & N.S \\
\hline $\mathbf{2 4}$ hrs & 10 & 3.18 & 0.09 & 2.9 & 3.8 & -1.5 & N.S \\
\hline
\end{tabular}

The mean level \pm S.E of serum total protein in normal rats was found to be $5.89 \pm 0.18 \mathrm{~g} / \mathrm{L}$

Table (5): Effect of sublethal dose $\left(\mathrm{LD}_{25}\right)$ of the hot water extract of sea cucumbers Holothuria atra on total protein of rats compared to normal controls.

\begin{tabular}{|l|l|l|l|l|l|l|l|}
\hline Groups & Number & Mean & S.E & Minimum & Maximum & \% Change & P< \\
\hline Control & 10 & 42.1 & 0.97 & 37 & 47 & - & - \\
\hline $\mathbf{1} / \mathbf{h}$ hrs & 10 & 53.7 & 3.80 & 34 & 79 & 27.1 & N.S \\
\hline $\mathbf{1}$ hrs & 10 & 54.8 & 2.80 & 41 & 71 & 30.1 & 0.05 \\
\hline 6 hrs & 10 & 93.5 & 2.37 & 85 & 109 & 122 & 0.05 \\
\hline $\mathbf{1 2}$ hrs & 10 & 42.0 & 2.62 & 34 & 57 & -0.23 & N.S \\
\hline $\mathbf{2 4}$ hrs & 10 & 42.0 & 2.48 & 34 & 60 & -0.23 & N.S \\
\hline
\end{tabular}

\section{Kidney function tests}

The mean level \pm S.E of serum Urea in normal rats was found to be $42.1 \pm 0.97 \mathrm{~g} / \mathrm{L}$. Table (6) showed that the level of Urea was significantly affected in rats injected (i.P) with $\mathrm{LD}_{25}$ of the extract of sea cucumber $H$. atra a sharp significant increase of Urea level reaching the maximum value after 6 hours of injection $(122 \% \mathrm{P}<0.05)$, then decreased throughout the experiment period, until reaching to non-significant affected after 12 hours (Table 6). However, Table (7) showed that the level of creatinine was 
significantly affected in rats injected (i.P) with $\mathrm{LD}_{25}$ of the extract of sea cucumber Holothuria atra a sharp significant increase of creatinine level reaching the maximum value after 6 hours of injection $(112.5 \% \mathrm{P}<0.05)$, then decreased throughout the experiment period. Reaching its normal base line after 24 hours.

Table (6): Effect of sublethal dose $\left(\mathrm{LD}_{25}\right)$ of the hot water extract of sea cucumbers Holothuria atra on Urea of rats compared to normal controls.

\begin{tabular}{|l|l|l|l|l|l|l|l|}
\hline Groups & Number & Mean & S.E & Minimum & Maximum & \%Change & P< \\
\hline Control & 10 & 42.1 & 0.97 & 37 & 47 & - & \\
\hline $\mathbf{1} \mathbf{2}$ hrs & 10 & 53.7 & 3.80 & 34 & 79 & 27.1 & N.S \\
\hline $\mathbf{1 ~ h r s ~}$ & 10 & 54.8 & 2.80 & 41 & 71 & 30.1 & 0.05 \\
\hline $\mathbf{6} \mathbf{~ h r s}$ & 10 & 93.5 & 2.37 & 85 & 109 & 122 & 0.05 \\
\hline $\mathbf{1 2}$ hrs & 10 & 42.0 & 2.62 & 34 & 57 & -0.23 & N.S \\
\hline $\mathbf{2 4}$ hrs & 10 & 42.0 & 2.48 & 34 & 60 & -0.23 & N.S \\
\hline
\end{tabular}

Table (7): Effect of sublethal dose $\left(\mathrm{LD}_{25}\right)$ of the hot water extract of sea cucumbers Holothuria atra on Creatnine of rats compared to normal controls.

\begin{tabular}{|l|l|l|l|l|l|l|l|}
\hline Groups & Number & Mean & S.E & Minimum & Maximum & \% Change & P< \\
\hline Control & 10 & 0.715 & 0.05 & 0.5 & 1.0 & - & - \\
\hline 1/2 hrs & 10 & 0.83 & 0.04 & 0.6 & 1.1 & 16.90 & 0.05 \\
\hline 1 hrs & 10 & 0.81 & 0.04 & 0.6 & 1.1 & 14.00 & 0.05 \\
\hline 6 hrs & 10 & 1.52 & 0.14 & 0.5 & 2.1 & 112.5 & 0.05 \\
\hline 12 hrs & 10 & 1.13 & 0.04 & 0.9 & 1.3 & 58.0 & 0.05 \\
\hline $\mathbf{2 4}$ hrs & 10 & 0.70 & 0.06 & 0.5 & 1.0 & -1.3 & N.S \\
\hline
\end{tabular}

The mean level \pm S.E of serum creatinine in normal rats was found to be $600.1 \pm 27.47 \mathrm{~g} / \mathrm{L}$

\section{DISCUSSION}

Classical examples of the use of natural marine extract (natural toxins) as experimental probes are the hot water extract of sea cucumber. Accordingly, this study was planned to understand the mechanism by which this extract of sea cucumber interfere with some of the most important biochemical and hematological analyses.

Firstly, this study started with the determination of the toxicity study shown in Table (1), the lethal dose, the median lethal dose $\left(\mathrm{LD}_{50}\right)$ and the sublethal dose $\left(\mathrm{LD}_{25}\right)$ of the extract of sea cucumber Holothuria atra, being 5, 3.12 and $1.55 \mathrm{mg} / \mathrm{Kg}$ rat, respectively. These results differ from those recorded by Yamanouchi (1955), who found the lethal dose of the same toxin extracted from sea cucumber, Holothuria vagabonds was $0.75 \mathrm{mg} / \mathrm{Kg}$ body weight in mice by intravenous and $70 \mathrm{mg} /$ the subcutaneous injection. These conflicts may be due to difference in the species of the sea cucumber, the species of the experimental animal and/ or the route of administration. The present findings agree with those of Zaki (2005), who found that the lethal dose, the median lethal dose $\left(\mathrm{LD}_{50}\right)$ and the sublethal dose $\left(\mathrm{LD}_{25}\right)$ of the extract of sea cucumber Holothuria atra, being 5, 3.9 and $1.50 \mathrm{mg} / \mathrm{Kg}$ rat, respectively. 


\section{Effect of sea cucumbers Holothuria atra extract on liver and kidney functions in rats}

Serum enzymes analysis proved to be very useful for liver diseases diagnosis. Serum alanine aminotransferase (ALT/ GPT) and aspartate aminoferase (AST/ GOT) serve as markers for hepatocellular damage. These enzymes are of significant impotence in assessing and monitoring of liver cell inflammation and necrosis which result in the release of these enzymes in circulation due to increase in permeability of the cell membrane or breakdown of cells Talwer $\boldsymbol{e t}$ al., 1989. Serum (ALT) measurement is more liver-specific than (AST). Aspartate aminotransferase (AST) has both cytoplasmic and mitochondrial isoenzymes, and tends to be released more than ALT in chronic hepatocellular disease (e.g. cirrhosis).

Data present in Table (3) the increase in serum activity of ALT after 30 minute and reach to sever increasing after 6 hours from extract injection in rats may be due to the minor hepatocellular toxicity induced by liver toxification mechanism. This result agreement with those of Ridzwan Bin Hashim et al. (2014) who found that the liver toxicity was confirmed by his pathological examination which indicated the present of hepatocellular toxicity after injection of rat by hot water extract of sea cucumber.

Data present in Tables ( 4 \& 5) showed insignificant effect of the sea cucumber extract on albumin and total protein in rats this result is disagreement with those reported by Zaki (2005), who reported a significant increase in total protein level after 24 hours of injection the rats by sea cucumber extract.

The obtained data Table (6) revealed a significant increase in serum urea level after $1 / 2$ and one hour then highly increase after 6 hour post injection. The present finding agree with Zaki (2005), who reported a significant increase in serum of urea level after 24 hours of injection the rats by sea cucumber extract.

Data present in Table (7) showed very highly increase in the serum level of creatinine of rats after 6 hour, blood urea nitrogen and creatinine are an indication of renal (kidney) health. The main causes of an increase in serum urea are high protein diet. The present findings agree with those of Abu-Amra et al. (2002), who used tetrodotoxin extracted from ovary and liver of the same puffer fish injected in rats. This explanation is concordant with Varly (1976), who stated that increased protein breakdown, which occurs in fevers, cardiac failure, and other toxic condition, may cause a moderate increase in serum urea level. Thus our results of the highly increase of serum urea and creatinine may due to the extract of sea cucumber contain large quantity protein, so sea cucumber is unsuitable for people have kidney disease, this not agree with Kazuhisa et al. (2003), who recommended that depolymerized holothurians glycosaminoglycan of sea cucumber is safe for use as anticoagulant during hemodialysis for kidney failure patients.

In conclusion, the extract toxin of sea cucumber of Holothuria atra has direct effect on ALT with no other effect of liver function test parameter, while has sharp effect on kidney function test parameters.

\section{REFERENCES}

Abu-Amra Abu-Amra, E.; Abd El-Rehim, E.; Khalifa, M.H. and Abd El-Satter, M. (2002). Effect of tetrodotoxin extracted from the ovary and liver of pufferfish, Arothron hispidus, on the kidney function in albino rat. J. Egypt Ger. Soc. Zool., 37 (A): 353-367.

Althunibat, O.S.; Hashim, R.B.; Taher, M.; Daud, J.M.; Zali, B.I. and Ikeda, M. (2009). In vitro antioxidant and antiproliferative activities of three Malaysian sea cucumber species Eur. J. Sci., 37 (3): 376-387. 
Mohamed A. Hamed et al.

Clark, A.M. (1967). Echinoderms from the Red Sea. Part 2 Crinoids Ophiorids, Echinoids and Asteroids, Bull. Seafish. Res. Sta. Haifa., 41: 26-58.

Doumas, B.; Watson, W. and Biggs, H. (1971). Albumin standards and the measurement of serum albumin with bromocresol green. Clin. Chim. Acta, 31: 87-96.

Fabiny, D. and Ertingshausen, G. (1971). Automated reaction-rate method for determination of serum creatinine with centrifichem. Clin. chem., 17: 696-700.

Fabiny, D. and Ertingshausen, G. (1971). Automated reaction-rate method for determination of serum creatinine with centrifichem. Clin. chem., 17: 696-700.

Fredalina, B.D.; Ridzwan, B.H.; Abidin, A.A.; Kaswandi, M.A.; Zaiton, H.; Zali, I.; Kittakoop, P. and jais, A.M. (1999). Fatty acid compositions in local sea cucumber, Stichopus chloronotus, for wound healing. Gen. pharmacol., 33: 337-340.

Gella, F.; Olivella, T.; Cruz Pastro, M.; Arenas, J.; Moreno, R.; Durban, R. and Gomez, J. (1985). A simple procedure for routine determination of aspartate aminotransferase and alanine aminotransferase with pyridoxal phosphate. Clin. Chim. Acta, 153: 241-247.

Gornall, A.G.; Bardawill, C.S.; David, M.M. (1949). Determination of serum proteins by means of the Biuret reaction. J. Biol. chem., 177: 751-766.

Gutmann, I. and Bergmeyer, H.U. (1974). Methods of enzymatic Analysis, ed Bergmeryer HU, Academic press, NY. 4: 1794-1798.

Hasan, M.H. (2001). Taxonomical and biochemical studies on some species of class holothuroidea (Echinodermata) from the Red Sea. Ph.D. Thesis, faculty of Science, Suez Canal University Ismailia, Egypt.

Hasan, M.H. (2003). Ecology and distribution patterns of the threatened holothuroid as correlated with over fishing in the Gulf of Aqaba, Northern Red Sea., Egypt. J. Egypt, Ger. Soc. Zool., 43 (D): 287-306.

Hasan, M.H. and Hasan, Y.S. (2004). Natural ecological factors and human impacts influencing the spatial distribution of holothuroids species in the Gulf of Aqaba. Egypt. J. Egypt. Ger. Soc. Zool., 43 (D): 287-306.

Hawa, I.; Zulaikah, M.; Jamaludin, M.; Zainal. A.; Kaswandi, M.A. and Ridzwan, B.H. (1999). The potential of the coelomic fluid in sea cucumber as an antioxidant. Department of Biomedical Science, Faculty of Allied Health Sciences, Universiti Kebangsaan Malaysia, Jalan Raja Muda A. Aziz, 50300 K. Lumpur, Malaysia.

Kazuhisa, M.; Keiko, K.; Hideki, N.; Eiji, S.; Katsuo, O. and Kenji, K. (2003). Kidney International, 63: 1548-1555.

Kerr, A.M. and Kim, J. (2001). Phylogeny of Holothuroidea (Echinodermata) inferred from morphology. Zool. J. Linn. Soc., 133: 63-81.

Reed, L.J. and Meuench, H. (1938). A simple method for estimating fifty percent end points. Am. J. Hyg., 37: 493-495.

Ridzwan, B.H. (2007). Sea cucumber: The Malaysian Heritage. Research center IIUM. Kuala Lumpur, Malaysia.

Ridzwan, H.; Nurul, A.; Zaitunnatakin, Z.; Farah, Z.; Nurzafirah, M. and Osama, A. (2014). Toxicity effects of water extracts of Holothuria atra Jaeger in mice. Asian Pacific J. Tropical Biomedicine. Kuala Lumpur, vol 4(8):614-617.

Sara, B.; Farooq, A. and Nazamid, S. (2011). High-value components and Bioactives from sea cucumbers for functional Foods. A Review. Marine Drugs, 9(10): 1761-1805.

Talwer, H. (1989). Clinical Chemistry. New York: John Wiley and Sons. pp. (4) 58-62. 


\section{Effect of sea cucumbers Holothuria atra extract on liver and kidney functions in rats}

Varley, H. (1976). Practical Clinical Biochemistry. $5^{\text {th }}$ edt. Platus press-B258. Enclave, New Delhi, India.

Yamanouchi, T. (1955). On the poisonous substance contained in holothurians. Publ. Seto. Mar. boil. Lab., 4: 183-202.

Zaki, M. (2005). Effects of the crud toxin of sea cucumbers Holothuria atra on some hematological and biochemical parameters in rats. Egypt. J. Natural Toxin, 2: 71-86.

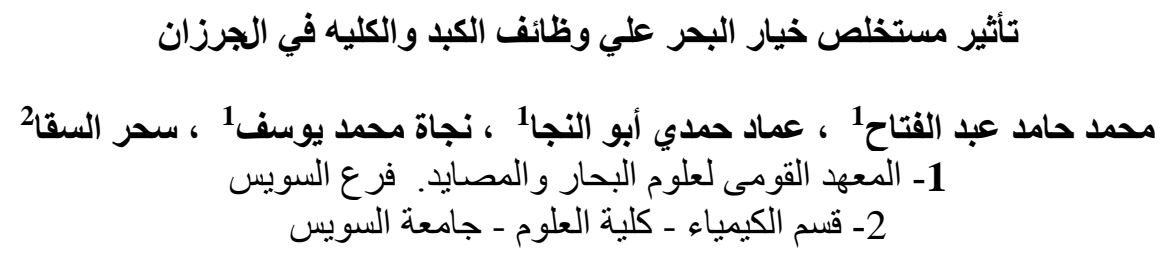

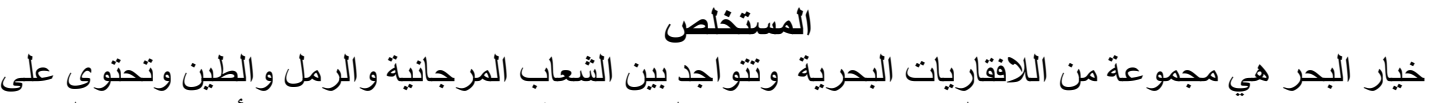

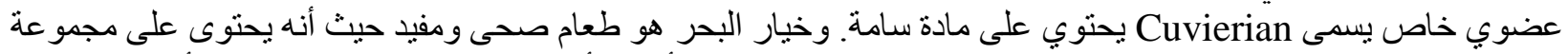

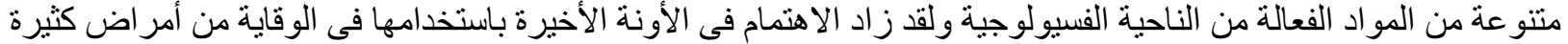
مثل امر اض القلب و الكبد ـ ولقد أجريت هذه الدراسة لمعرفة تأثير مستخلص خيار البحر

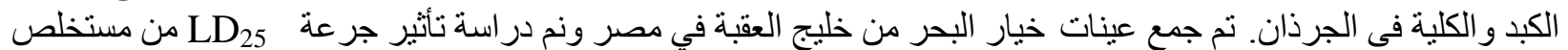

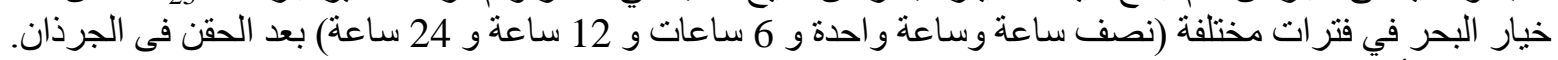

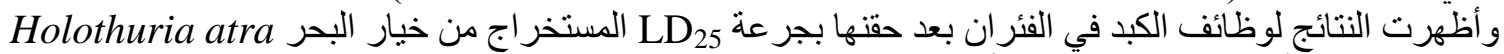

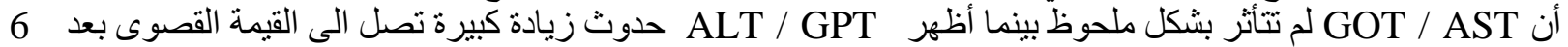

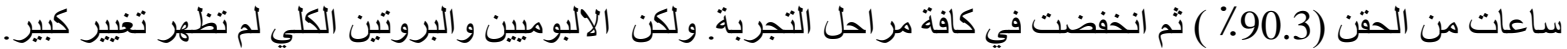

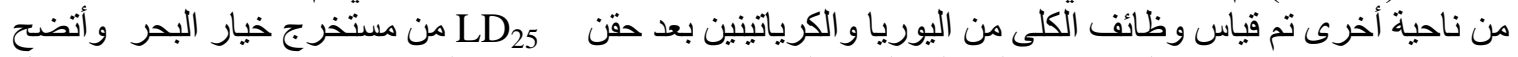

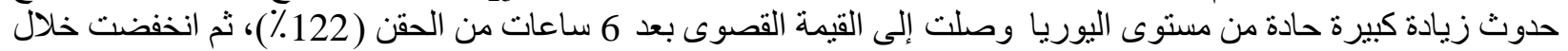

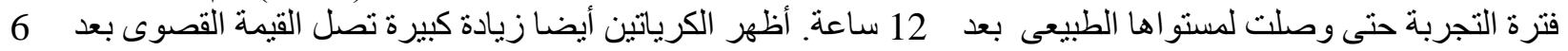
ساعات من الحقن ( 112.5٪) ثم انخفضت خلال التجربة مثل اليوريا ولكن الكرياتينين وصل إلى المستوى الطبيعي بعد 24

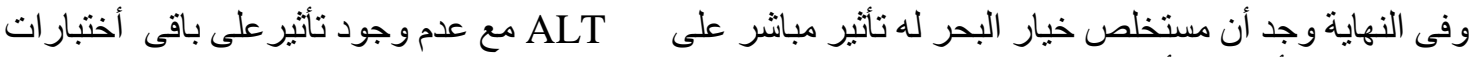
ساعة. وظائف الكبد ، في حين أن لديه تأثير حاد على اختبار وظائف لئف الكلى. 